\title{
SSR Marker Aided Introgression for opaque2 Allele for Development of Quality Protein Maize Inbreds
}

\author{
R. SINGH ${ }^{1 *}$, L. RAM ${ }^{1}$, R.K. SINGH ${ }^{2}$ and D. SINGH JAKHAR ${ }^{1}$ \\ ${ }^{1}$ Department of Genetics and Plant Breeding, Institute of Agricultural Sciences, Banaras Hindu University, \\ Varanasi-Uttar Pradesh-221005, India \\ ${ }^{2}$ Visiting Scientist, Plant Genome Mapping Laboratory, 111 River Bend Road, University of Georgia, \\ Athens, GA (USA)-30603
}

(Received 16 September 2016; Accepted 19 December 2016;

Communicated by A. Börner)

Maize protein quality is deficit in essential amino acids, lysine and tryptophan. These constraints of o2 (opaque2) are corrected in genetically improved, hard endosperm QPM (Quality Protein Maize). An integrated strategy of phenotypic selection for endosperm modifiers and molecular marker-assisted foreground and background selection has been used in present study. The QPM donors were, CML 161, DMRQPM 58, CML 176 and CML 141 whereas, normal maize inbreds were CM 212, V338, V361, V336, V341, V351, CM 141 and V335. The inbreds were subjected to parental polymorphism survey between non-QPM and QPM using CIMMYT based three SSR markers, viz. phi057, umc1066 and phi112. Two markers, viz. phi057 and umc1066 exhibited co-dominant reactions, while phill2 was dominant in nature. Finally, two combinations V335 $\times$ CML 141 and V351 $\times$ CML 141 were considered for conversion program. Foreground selection was exercised using $o 2$ specific marker umc1066 in $\mathrm{BC}_{1}$ and $\mathrm{BC}_{2}$ generations, while background as well as foreground selection was exercised in $\mathrm{BC}_{2} \mathrm{~F}_{3}$ generation to recover the genome of recurrent parent up to extent of 80 to $100 \%$ with the help of SSR markers distributed across the whole maize genome. The tryptophan concentration in endosperm protein was significantly enhanced and the converted maize lines had almost twice the amount of lysine and tryptophan than normal maize inbreds.

Keywords: background and foreground selection, lysine, opaque2, QPM, tryptophan

\section{Introduction}

Maize is deficient in two essential amino acids, lysine and tryptophan. The QPM has about twice the levels of lysine and tryptophan as compared to normal maize. It was developed by combining the genetic systems of the gene mutant $o 2$ and modified $o 2$ endosperm (Prasanna et al. 2001; Vasal 2001; Krivanek et al. 2007; Sofi et al. 2009; Gupta et al. 2014; Ram et al. 2015; Singh and Srivastava 2015). The QPM breeding program is complex process, since it requires the simultaneous manipulation of three genetic systems; the 02 gene, the endosperm modifier genes, and the genes that control the lysine

\footnotetext{
*Corresponding author; E-mail: rsingh6361@gmail.com
} 
content (Moro et al. 1996). Although conventional breeding procedures to convert commercial lines to QPM forms are tedious and time consuming and is not directly targeted towards improvement of grain quality. The CIMMYT has validated and confirmed that three SSR primers, viz. phi057, phil12 and umc1066 are located as internal repetitive elements within o2 gene (Prasanna et al. 2001; Vasal 2001; Ram et al. 2015). These three primers are used in the PCR (Polymerase Chain Reaction) based assay to select individuals carrying a copy of the $o 2$ gene in successive backcrossed and selfed segregating generations. This is useful for breeders to discard non-QPM plants prior to pollination. The breeding population is reduced and it saves both time and money. Second, it also helps breeders to select either homozygous or heterozygous plants (Ribaut and Hoisington 1998). We are reporting an attempt to integrate high protein quality and hard endosperm traits through a combination of marker aided and phenotypic selection techniques. It is also demonstrated that foreground selection for $o 2$ in early $\left(\mathrm{BC}_{1}\right)$ generation combined with background selection for recipient genome at later $\left(\mathrm{BC}_{2}\right)$ generation results in rapid genetic gain and substantial cost savings.

\section{Materials and Methods}

\section{Plant materials}

Eight normal maize inbred lines (V335, CM 141, CM 212, V361, V338, V351, V341 and V336) and four QPM inbreds lines (CML 141, DMRQPM 58, CML 176 and CML 161) were selected based on field and parental polymorphism assay (Table 1). The present study was conducted during Rainy Seasons of 2011-2014 at Agriculture Research Farm, BHU, Varanasi-221005, India.

\section{DNA isolation, PCR and electrophoresis}

Genomic DNA was isolated from leaf samples of 21-25 days old seedlings. DNA was utilized for parental polymorphism survey and marker assisted selection (Fig. 1). For genomic DNA isolation, CTAB method was used with some modifications. PCR cycling

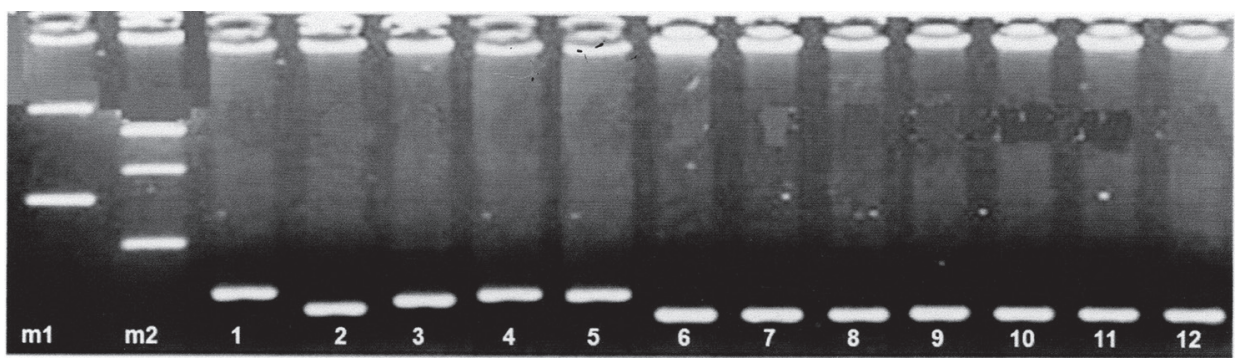

Figure 1. Parental polymorphism analysis using opaque2 specific SSR marker umc1066 between normal and QPM inbred lines. Lane 1: m1: $1 \mathrm{~kb}$ marker, Lane 2: $\mathrm{m} 2: 100$ bp marker and Lanes 3 to 14 as follow: $1-\mathrm{V} 335$, 2 - CM 141, 3 - CM 212, 4 - V361, 5 - V338, 6 - V351, 7 - V341, 8 - V336 (all normal inbreds) 9 - CML 141, 10 - DMRQPM 58, 11 - CML 176 and 12 - CML 161 (all QPM) 
Table 1. Characteristic features, pedigree and sources of non-QPM lines (8) and QPM donors (4) used in present study

\begin{tabular}{|c|c|c|}
\hline Inbred name & Pedigree and source & Characteristic features \\
\hline V335 & TZI-25, VPKAS, Almora & $\begin{array}{l}\text { Orange, Flint kernel, Medium duration, Straight } \\
\text { tassel }\end{array}$ \\
\hline CM 141 & Pool 33 (Alm), VPKAS, Almora & Yellow kernel, Late duration, Curved tassel \\
\hline CM 212 & USA/ ACC No. 2132 (Almora) & $\begin{array}{l}\text { Medium maturity, medium plant and cob height } \\
\text { with good yield }\end{array}$ \\
\hline V361 & Selection from population 31 & $\begin{array}{l}\text { Medium-early maturity good Vigour, Resistant } \\
\text { Turcicum leaf blight }\end{array}$ \\
\hline V338 & B10 45010, VPKAS, Almora & Early maturity and yield is average \\
\hline V351 & Shakti (So) HE 25, VPKAS Almora & $\begin{array}{l}\text { Orange yellow, Flint kernel, Early duration, } \\
\text { better grain yield }\end{array}$ \\
\hline V341 & Mexico Acc No.3136@-3-2-3-8-1 & $\begin{array}{l}\text { Yellow, Flint kernel, Early duration, drooping } \\
\text { leaf, straight tassel }\end{array}$ \\
\hline V336 & $\begin{array}{l}\text { CML 145, P63CDHC181-3-2-1-4 } \\
\text { \#2-BBBB \#F-BBBBB\# VPKAS, } \\
\text { Almora }\end{array}$ & $\begin{array}{l}\text { Yellow, Flint kernel, Medium duration, Leaf and } \\
\text { Tassel angle is small, Straight leaf attitude }\end{array}$ \\
\hline CML 141 (QPM) & Pop 62, CIMMYT & White, Flint kernel, Late duration, Dwarf height \\
\hline $\begin{array}{l}\text { DMRQPM } 58 \\
(\mathrm{QPM})\end{array}$ & Shakti 1, DMR & $\begin{array}{l}\text { Orange yellow, Flint kernel, Early duration, Tall } \\
\text { height }\end{array}$ \\
\hline CML 176 (QPM) & (P63-12-2-1/P67-5-1-1)-1-2-B-B ) & White kernel, Medium to Late duration \\
\hline CML 161 (QPM) & P 25QPM, CIMMYT & $\begin{array}{l}\text { Orange yellow, Flint kernel, Late duration, } \\
\text { Dwarf height }\end{array}$ \\
\hline
\end{tabular}

consisted of initial denaturation at $94{ }^{\circ} \mathrm{C}$ for $2 \mathrm{~min}$, followed by $30-35$ cycles of amplification at $94{ }^{\circ} \mathrm{C}$ for $1 \mathrm{~min}, 55-65^{\circ} \mathrm{C}$ for $1 \mathrm{~min}$ and $72{ }^{\circ} \mathrm{C}$ for $2 \mathrm{~min}$. A final extension step at $72{ }^{\circ} \mathrm{C}$ for 7 min was followed by termination of the cycle at $4{ }^{\circ} \mathrm{C}$. The amplified products $(15 \mu \mathrm{l})$ were resolved on a $3.5 \%$ high-resolution agarose gel (Super Fine Resolution (SFR) agarose; Amresco, USA) on a submarine gel electrophoresis system (Biorad, model 196), following the procedure suggested by Senior et al. (1998). The gels were visualised by ethidium bromide and photographed by Gel Documentation System GeNei ${ }^{\mathrm{TM}}$ for further analysis.

\section{Parental polymorphism assay}

For the present study, the selection for $o 2$ was performed using three SSR primers, viz. phi057, phi112 and umc1066 located as internal repetitive elements within $o 2$ gene. For the selection, phi057 or umc1066 were used to identify heterozygous progenies carrying $o 2$ gene in backcross and segregating generations, whereas marker phil12 exhibited dominant polymorphism between normal and QPM inbreds. The SSR marker, umc1066 amplified 140 bp fragments in all 4 QPM lines (Table 1) and 155-165 bp fragment in all 8 normal lines (Fig. 1). 


\section{Marker assisted selection in back cross generation}

The agronomic evaluation, parental polymorphism survey, heterosis, SCA (Specific Combining Ability) and GCA (General Combining Ability) studies of normal maize inbreds and QPM inbreds lines finally led to selection of the two non-QPM inbreds V335, V351 and one CIMMYT QPM donor CML 141 for the present conversion program. The $\mathrm{F}_{1} \mathrm{~S}$ were attempted using recurrent parents V335 and V351 as female and QPM Donor CML 141 as male parent during winter 2011-2012. $\mathrm{F}_{1} \mathrm{~s}$ of $\mathrm{V} 335 \times \mathrm{CML} 141$ and V351 $\times$ CML 141 were backcrossed with respective recurrent parents (V335 and V351) to obtain $\mathrm{BC}_{1}$ generations. Twofold selection strategies were adopted for selection in $\mathrm{BC}_{1}$ generations. (i) Selection of heterozygotes for $o 2$ gene specific to SSR marker umc1066 and (ii) the selected heterozygotes were subjected to phenotypic selection that resembled close to the Recurrent Parent (RP) (Fig. 3). The selected $\mathrm{BC}_{1}$ individuals were grown to raise the $\mathrm{BC}_{2} \mathrm{~F}_{1}$. The selected progenies were selfed to produce $\mathrm{BC}_{2} \mathrm{~F}_{2}$ seeds, the selected $\mathrm{BC}_{2} \mathrm{~F}_{2}$ individuals were raised to obtain $\mathrm{BC}_{2} \mathrm{~F}_{3}$ generations. Again twofold strategies were adopted, first $\mathrm{BC}_{2} \mathrm{~F}_{3}$ progenies were subjected to molecular screening with SSR marker umc1066 for frequent selection before flowering to identify the progenies that attained homozygosity at $o 2$ locus (Fig. 2). Standard $\chi 2$ (Chi square) test was used to test the segregation of pattern at each marker locus from the expected Mendelian segregation ratio of 1:1 for each of backcross population. About 175 SSR markers earlier identified from polymorphism studies of maize inbreds (Singh and Srivastava 2015) were used to screen the respective recurrent parents and donor parents to recover the RPG (Recurrent Parent
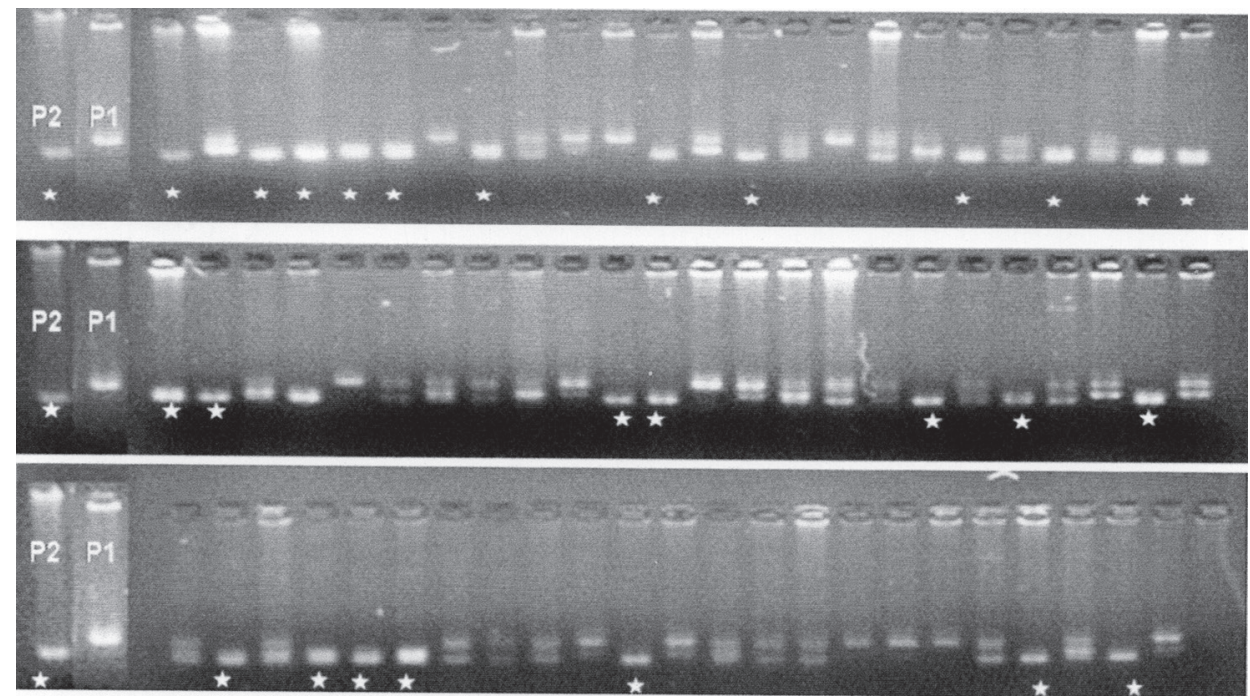

Figure 2. Identification of homozygous recessive individuals in $\mathrm{BC}_{2} \mathrm{~F}_{2}$ generation of $[(\mathrm{V} 335 \times \mathrm{CML}$ $141) \times$ V335] employing umc1066. The first two lanes correspond to donor parent-QPM (P2) and recurrent parent-non QPM (P1) while rests are individuals of $\mathrm{BC}_{2} \mathrm{~F}_{2}$ population. The individuals indicated by * are homozygous recessive for opaque-2 mutant allele 
Genome). These polymorphic markers were used in backcross generations to regain the RPG in the respective cross. The 98 and 96 SSR primers were identified to be used in recovery of RPG for the crosses; V335 × CML 141 and V351 × CML 141, respectively.

\section{Light box screening}

The genotypes being homozygous recessive for $o 2$ locus were identified in $\mathrm{BC}_{2} \mathrm{~F}_{2}$ generations were subjected to light box test to measure the intensity of kernel modification. The kernels of $\mathrm{BC}_{2} \mathrm{~F}_{3}$ were screened by placing them on a light box and white light was passed through seeds. The kernel were classified into 5 classes based on visual observations of endosperm vitreousness 1: $0 \%, 2: 1-25 \%, 3: 26$ to $50 \%, 4: 51$ to $75 \%$ and $5: 76$ to $100 \%$ opaqueness.

\section{Protein and tryptophan analysis}

The biochemical analysis for total protein content in the endosperm and tryptophan concentration in endosperm protein in each class of kernel modification were carried out according to standard procedures developed by Villegas and Mertz (1975) and Villegas et al. (1984). The grain samples were de-germed after removing the pericarp and finely ground. The resulting flour was defatted and total nitrogen content was determined by Microjeldahl procedure and percentage of protein was calculated by multiplying the $\mathrm{N}$ content with a factor of 6.25. The tryptophan concentration in endosperm protein was estimated by the colorimetric method of Hernandez and Bates (1969).

\section{Results}

\section{Identification of recurrent and donor parents}

Twelve lines involving 8 normal and 4 QPM inbred were identified. The SSR phil12 exhibited dominant polymorphism among 8 normal and 4 QPM lines. The markers, viz. phi057 and umc1066 exhibited co-dominant polymorphism between normal and QPM lines. This helped in identification of two parental combinations, viz. V335 (non-QPM) vs CML 141 (QPM donor) and V351 (non-QPM) × CML 141 (QPM) for conversion program (Fig. 3).

\section{Foreground and background selection}

In the $\mathrm{BC}_{1}$ population of $\mathrm{V} 335 \times \mathrm{CML} 141,88$ plants were heterozygous for $o 2$ gene and 130 exhibited dominant homozygous, whereas 2 did not express any band out of total of 220 plants (Fig. 3 and Table 2). Similarly, the other cross (V351 $\times$ CML 141) contained 96 heterozygotes and 120 dominant homozygotes, whereas 4 did not express any band, out of total 220 plants. The selection of heterozygotes $(\mathrm{Qq})$ of $o 2$ at early stages of plant 
Table 2. Selection of heterozygous/homozygous plants for opaque2 by the marker umc1066 in [(V335 $\times \mathrm{CML}$ $141) \times$ V335] and [(V351 $\times$ CML 141) $\times$ V351] segregating populations

\begin{tabular}{|c|c|c|c|c|c|}
\hline Generations & $\begin{array}{l}\text { No. of plants } \\
\text { scored }\end{array}$ & $\begin{array}{c}\text { Dominant } \\
\text { homozygous }(\mathrm{O} 2 \mathrm{O} 2)\end{array}$ & $\begin{array}{l}\text { Heterozygous } \\
(\mathrm{O} 2 \mathrm{o} 2)\end{array}$ & $\begin{array}{c}\text { Recessive } \\
\text { homozygous } \\
(o 2 o 2)\end{array}$ & Chi-square test \\
\hline \multicolumn{6}{|c|}{$[(\mathrm{V} 335 \times \mathrm{CML} 141) \times \mathrm{V} 335]$} \\
\hline $\mathrm{BC}_{1} \mathrm{~F}_{1}$ & 220 & 130 & 88 & - & $* *$ \\
\hline $\mathrm{BC}_{2} \mathrm{~F}_{1}$ & 220 & 122 & 96 & - & Ns \\
\hline $\mathrm{BC}_{2} \mathrm{~F}_{2}$ & 240 & 56 & 101 & 76 & Ns \\
\hline \multicolumn{6}{|c|}{$[(\mathrm{V} 351 \times \mathrm{CML} 141) \times \mathrm{V} 351]$} \\
\hline $\mathrm{BC}_{1} \mathrm{~F}_{1}$ & 220 & 120 & 96 & - & Ns \\
\hline $\mathrm{BC}_{2} \mathrm{~F}_{1}$ & 220 & 114 & 104 & - & Ns \\
\hline $\mathrm{BC}_{2} \mathrm{~F}_{2}$ & 240 & 70 & 96 & 68 & Ns \\
\hline
\end{tabular}

** Significant at $1 \%$ level of significance. Ns = non-significant at $1 \%$ level of significance.

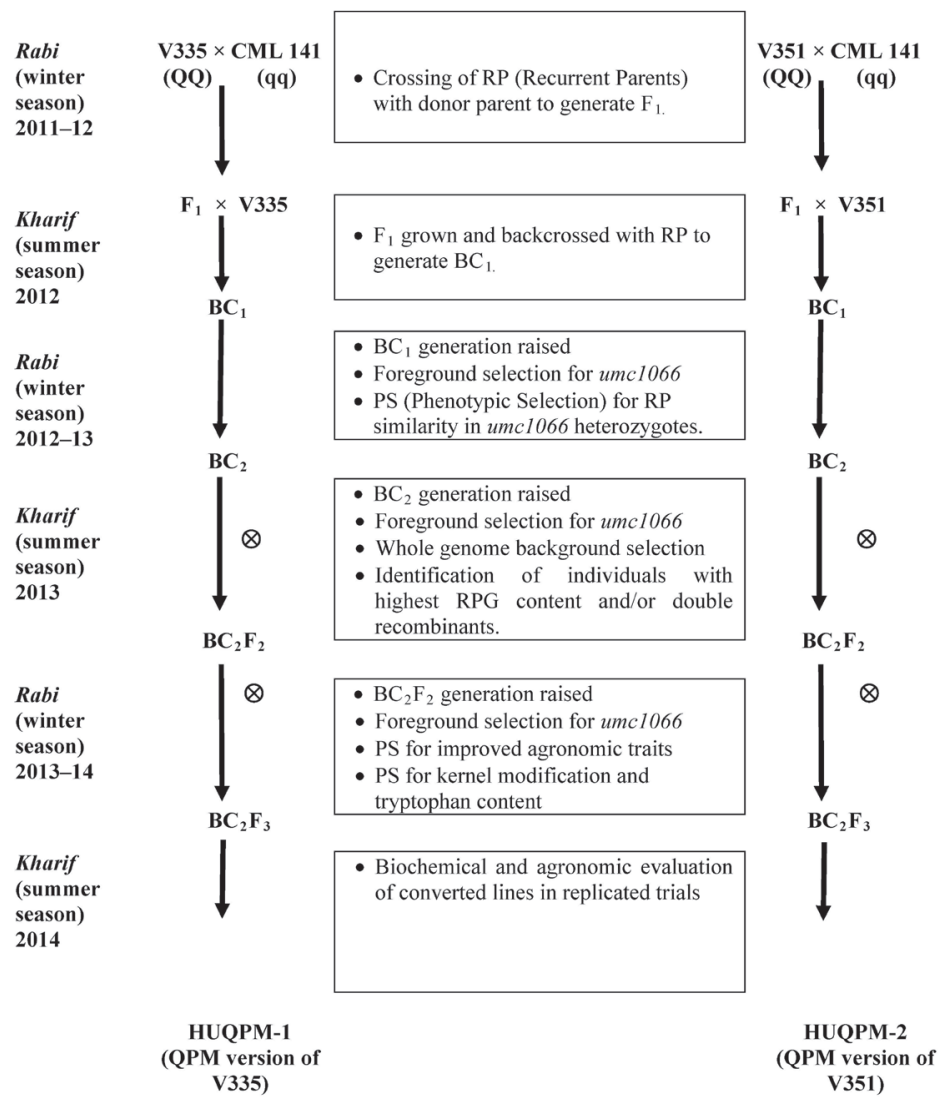

Figure 3. A schematic diagram showing simultaneous conversion of normal inbreds to quality protein maize 
growth (21-25 days of planting) before pollination, helps in elimination of non-target BC progenies (dominant homozygous) resulting in substantial labor and resource saving. The selected individual heterozygotes were further backcrossed to respective recurrent parents to further advance the generation to $\mathrm{BC}_{2}$ (Fig. 3). After light box test and other visual phenotypic selection a population size of 220 plants (Table 2) were maintained in $\mathrm{BC}_{2}$ generation for both the crosses. With the help of SSR primers umc1066 foreground selection was again exercised in $\mathrm{BC}_{2}$ generation (Fig. 2), which helped in elimination of about 122 and 114 progenies having dominant homozygotes (QQ) and retaining 96 and 104 heterozygous $(\mathrm{Qq})$ individuals for the crosses V335 × CML 141 and V $351 \times \mathrm{CML} 141$, respectively. The marker assisted selected heterozygotes in $\mathrm{BC}_{2}$ were subjected to background selection using 98 and 96 SSR markers in the crosses V $335 \times$ CML 141 and V $351 \times$ CML 141, respectively. These SSR markers spanning all over the 10 chromosome of maize genome were effective for background selection to recover RPG. The recipient progenies $\left(\mathrm{BC}_{2}\right)$ genome content varied from 80 to $100 \%$ and 85.7 to $100 \%$, in two crosses $\left(\mathrm{V} 335 \times \mathrm{CML} 141\right.$ and V351 $\times$ CML 141), respectively. Ears from $\mathrm{BC}_{2}$ progenies in each cross that contained maximum percentage of $\mathrm{RPG}$ were selected for raising the $\mathrm{BC}_{2} \mathrm{~F}_{2}$ generation. The selfing of $\mathrm{BC}_{2} \mathrm{~F}_{1}$ to $\mathrm{BC}_{2} \mathrm{~F}_{2}$ about 240 plants were maintained in each cross. Further, the molecular screening led to identification of 101 and 96 heterozygotes (Qq), which were retained and 56 and 70 dominant homozygotes (QQ) were rejected, further 76 and 68 recessive homozygotes (qq) were also retained in two crosses, viz. V335 × CML 141 and V351 × CML 141, respectively.

\section{Selection in $\mathrm{BC}_{2} \mathrm{~F}_{2}$ and $\mathrm{BC}_{2} \mathrm{~F}_{3}$ generation}

Ears from the five $\mathrm{BC}_{2} \mathrm{~F}_{2}$ progenies in each cross that contained maximum amount of $\mathrm{RPG}$ and phenotypically similar to $\mathrm{RP}$ were chosen for developing $\mathrm{BC}_{2} \mathrm{~F}_{3}$ generation to fix the $o 2$. The homozygous (qq) $\mathrm{BC}_{2} \mathrm{~F}_{3}$ seeds for $o 2$ allele were subjected to light box test to identify the intensity of kernel modification. In each cross, it could be observed through light box screening. With the help of o2 specific SSR marker umc1066, the 76 selected progenies for cross V335 × CML 141 and 68 for cross V351 × CML 141 were again subjected to phenotypic selection. The newly converted QPM inbred HUQPM-1 and HUQPM-2 were phenotypically near to their original inbred V335 and V351, respectively, with some differences were observed (Table 3). The plant height of HUQPM-1 increased by $6 \mathrm{~cm}$ and $10 \mathrm{~cm}$ as compared to V335 and CML 141, respectively, whereas placement of ear height was also increased by $3 \mathrm{~cm}$ and $7 \mathrm{~cm}$ as compared to V335 and CML 141, respectively. With respect to days to $50 \%$ silking and days to $50 \%$ tasseling the converted HUQPM-1 was early (10 days) as compared to CML 141 but near to V335, recipient parent indicated the high parentage recovery of recurrent parent. As targeted there were $81 \%$ increases in tryptophan content and $2.10 \%$ increase in total protein content in cross V335 $\times$ CML 141, whereas 102\% increase in tryptophan content and $1.6 \%$ increase in total protein content in cross V351 $\times$ CML 141 were also observed (Table 3). 


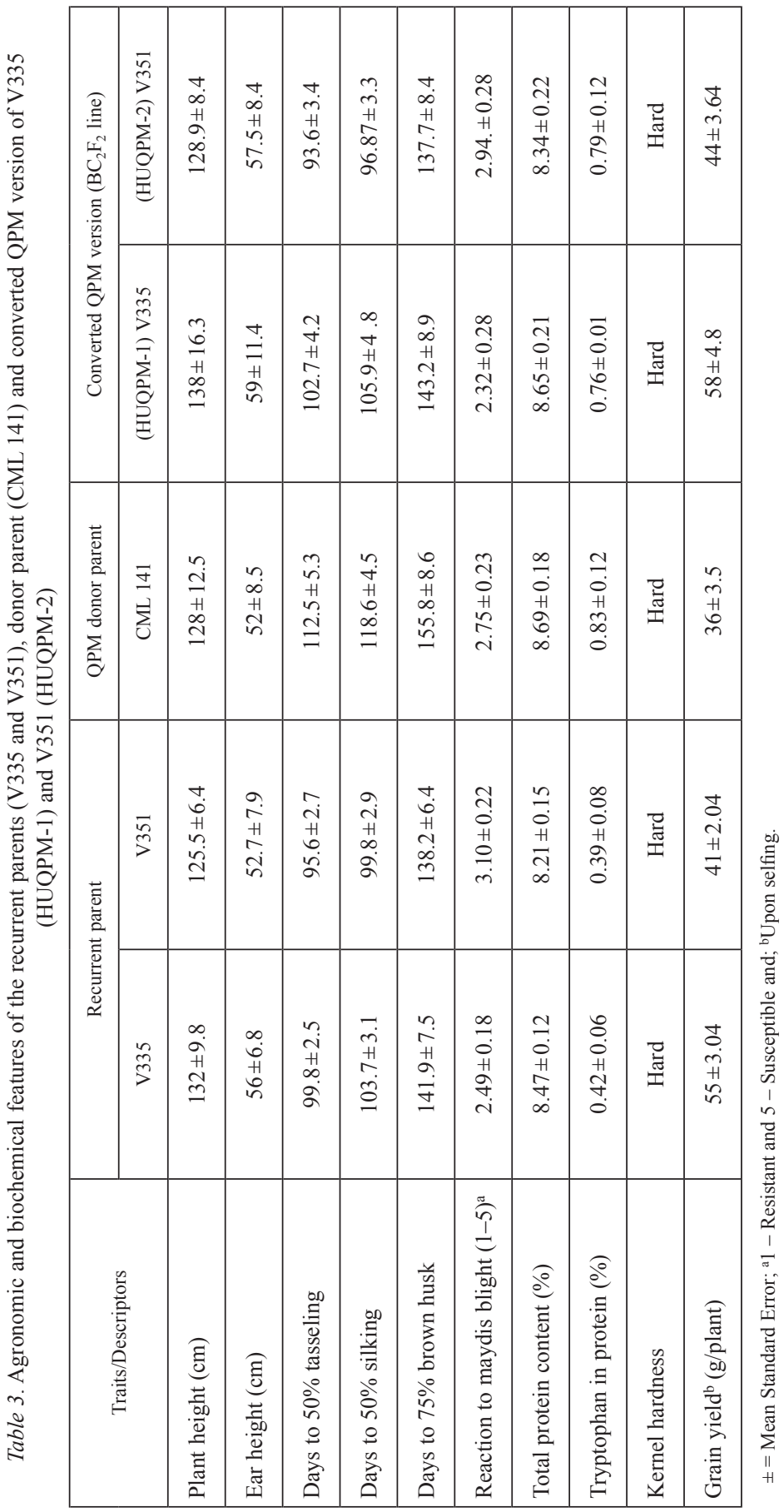

Cereal Research Communications 45, 2017 


\section{Discussion}

The normal maize protein is of poor nutritional quality due to the deficiency in two amino acids (lysine and tryptophan) and high leucine-isoleucine ratio. A breakthrough came in the $1960 \mathrm{~s}$, with the discovery of the enhanced nutritional quality of the maize mutant $o 2$ (Mertz et al. 1964). The $o 2$ gene is recessive and modifiers are polygenic. Their introgression into elite inbreds is not a straight forward procedure. Keeping this in view a rapid maize inbred conversion program based on two generation backcross conversion programme with the help of foreground and background were followed. The present investigation establishes successful conversion of normal maize inbreds into QPM version, possessing high lysine and tryptophan content in kernels through marker assisted back crossing. Earlier Gupta et al. (2014) have also reported similar conversion using 3 SSR molecular markers to local maize inbred lines CM 212 and CM 145. Although 3 SSR markers (phi112, phi057 and umc1066) were available for o2 locus, but only umc1066 showed polymorphism between recurrent parent and donor parent, which were inherited co-dominantly. In the present study polymorphism could be observed between the normal and QPM inbreds lines with all the 3 SSR markers. However, the nature of polymorphism was different with respect to phi112, which exhibited dominant (presence-absence) polymorphism, restricting its potentiality in identifying the three forms of genotypes (QQ, Qq, qq) for the $o 2$ gene. Nevertheless, such presence-absence polymorphism is only of limited use, because it could not be used in discriminating homozygous (QQ) and heterozygous (Qq) in the backcross progenies. The presence of this particular marker could be used in checking the fidelity of inbred lines.

Co-dominant nature of the polymorphism was exhibited by phi057 and umc1066, between normal and QPM inbreds. Such co-dominant polymorphism enables their potential utility in MAS progenies as they could successfully discriminate between all the 3 possible genotypes for the $o 2$ gene, viz. dominant homozygote (QQ) and heterozygote (Qq) and recessive homozygote (qq). Gupta et al. (2014) reported conversion of normal maize inbred lines into QPM version using SSR marker umc1066 as co-dominant marker for screening parental lines as well as segregating backcross generations $\left(\mathrm{BC}_{1}\right.$ and $\left.\mathrm{BC}_{2}\right)$. The study also revealed that polymorphism was not obtained among all the QPM donors and all the normal maize inbred lines. In initial stage, 23 normal maize and 12 QPM donors were included in the present study, later they were screened to 8 normal maize inbred (non-QPM) and only 4 QPM donors based on adaptability and polymorphism studies. The present investigation follows the similar trend as reported by Gupta et al. (2014) who found that SSR marker umc1066 exhibiting polymorphism between QPM and non-QPM inbreds and they further established that polymorphism may not be obtained between all the normal inbreds and QPM donors with these 3 SSR markers. So, it is advisable to keep on screening for new QPM donors as well as recipient parent in a marker aided QPM backcross breeding program. The gene specific markers such as phi057 and umc1066, which are localized within the $o 2$ gene itself, the genuine individual plants in any segregating population, could be scored directly for the gene. The possibility of occurrence of false positives and false negatives in segregating population is thus eliminated. It is dif- 
ficult to find such markers for most of the traits/genes, unless they are already cloned and sequenced. Further, the problem of selecting genotypes carrying undesirable gene due to the linkage drag, a usual phenomenon that occurs while transferring QTLs with QTL flanking markers (Tanksley 1993) was not encountered in the present study.

Foreground selection using phi057 or umc1066 could identify heterozygous (Qq) progenies that occurred in about $50 \%$ frequency in a given back cross population. The background selection was exercised with the help of 98 and 96 SSR markers in the respective crosses distributed across the all 10 linkage groups of the maize. These markers have also been utilized in parental polymorphism studies by Singh and Srivastava (2015). The main aim of the background selection is to rapidly recover maximum proportion of RPG at non target loci with the help of molecular markers distributed evenly throughout the genome (Young and Tanksley 1989; Hospital et al. 1992; Visscher et al. 1996; Frisch et al. 1999). Maize is one of the advantageous crops with respect to information regarding molecular markers as well as robust anchored marker maps in maize renders application of marker aided background selection, a very existing and effective proposition. Past similar studies of Frisch et al. (1999) have indicated that application of background selection in one later generation along with the foreground selection in each $\mathrm{BC}$ generations is very effective and less costly. It may be mentioned here that employing background selection in each BC generations may not be affordable by many research groups, particularly in public sector breeding programme. So, in the present study, a two generation marker based breeding programme was applied in both the generation and background selection was applied in $\mathrm{BC}_{2}$ at non target loci. QPM germplasm faces problem of poor germination and insufficient kernel modification, keeping that in view marker aided background analysis was employed in $\mathrm{BC}_{2}$ generation and individual were selected with highest proportion of RPG for next generation of selfing. Ram (2014) has also adopted similar breeding strategy by selecting $\mathrm{BC}_{2}$ individual with highest proportion of RPG for developing further $\mathrm{BC}_{2} \mathrm{~F}_{2}$ families. In the present study we employed foreground selection in an early $\left(\mathrm{BC}_{1}\right)$ generation combined with background selection at later stages $\left(\mathrm{BC}_{2}\right)$ along with the phenotypic selection for quantitative and continuously distributed traits, which resulted in rapid conversion and genetic gain in a cost effective manner. $\mathrm{BC}_{2} \mathrm{~F}_{1}$ was selfed to obtain $\mathrm{BC}_{2} \mathrm{~F}_{2}$, where kernels segregated for hardness at different levels of modification. The frequencies of completely modified kernels (0\%) and fully opaque (100\%) was very low. This indicates about several minor genes controlling kernel modification in QPM. Lopes and Larkins (1995) revealed existence of two additive modifier genes that significantly affect the endosperm modification in their population. Vasal et al. (2001) reported that $o 2$ allele is recessive and the endosperm modifiers are polygenic with no reliable molecular marker identified for kernel modification. Phenotypic screening of the individual kernel under transmitted light and selection of kernels that have less than $25 \%$ opaqueness is by far the most convenient and efficient strategy employed in the QPM breeding programme. The biochemical analysis of kernel modification showed that tryptophan concentration in protein is the chief indicator of protein quality which was enhanced between 81 to $102 \%$ in two crosses as compared to recipient parents. Lysine proportion in protein was not estimated due to the strong positive correlation between two 
amino acids in endosperm protein (Pixley and Bjarnasan 1993). There was improvement in protein content $(1.6-2.1 \%)$ of converted lines.

The agronomic traits such as days to $50 \%$ tasseling, resistance to TLB and MLB, pollen shedding ability, grain yield and plant height were the criteria to exercise selection in marker selected $o 2$ progenies in the $\mathrm{BC}_{2} \mathrm{~F}_{2}$ generation. The converted lines HUQPM-1 (V335) and HUQPM-2 (V351) were subject to phenotypic selection including light box test in $\mathrm{BC}_{2} \mathrm{~F}_{2}$ and onward generation for combining desirable agronomy traits with superior protein quality and hard endosperm traits. The evaluation of newly bred converted QPM lines, viz. HUQPM-1 and HUQPM-2 were phenotypically near to their original lines, viz. V 335 and V 351, respectively, but there was some difference in plant heights 5-10 cm. The present study establishes the successful conversion of normal maize inbreds (non-QPM) to QPM inbreds, possessing high lysine and tryptophan content. The breeding strategy brings together the salient features of marker aided and phenotypic selection and as such fixing a large segregating population for target locus, reduction linkage drag by selecting linking markers of the recipient allele type, recovery of RPG with $\mathrm{BC}_{2}$ generation and providing scope for exercising phenotypic selection for as may desirable agronomic and biochemical traits as possible.

\section{References}

Frisch, M., Bohn, M., Melchinger, A.E. 1999. Comparison of selection strategies for marker assisted backcrossing of a gene. Crop Sci. 39:1295-1301.

Gupta, H.S., Babu, R., Agarwal, P.K., Mahajan, V., Hossian, F., Nepolean, T. 2014. Accelerated development of Quality Protein Maize hybrids through marker assisted introgression of opaque-2 allele. Plant Breed. 132:77-82.

Hernandez, H.H., Bates, L.S. 1969. A modified method for rapid tryptophan analysis in maize. CIMMYT Research Bulletin No. 13. CIMMYT. Mexico, D.F., Mexico.

Hospital, F., Chevalet, C., Mulsant, P. 1992. Using markers in gene introgression programs. Genetics 132:1199-1210.

Krivanek, A., Groote, H., Gunaratna, N., Diallo, A., Freisen, D. 2007. Breeding and disseminating quality protein maize for Africa. Afr. J. Biotechnol. 6:312-324.

Lopes, M.A., Larkins, B.A. 1995. Genetic analysis of opaque2 modifier gene activity in maize endosperm. Theor. Appl. Genet. 119:274-281.

Mertz, E.T., Bates, L.S., Nelson, O.E. 1964. Mutant gene that changes protein composition and increases lysine content of maize endosperm. Science 145:279-280.

Moro, G.L., Habben, J.E., Hamaker, B.R., Larkins, B.A. 1996. Characterization of the variability in lysine content for normal and opaque2 maize endosperm. Crop Sci. 36:1651-1659.

Pixley, K.V., Bjarnasan, M.S. 1993. Combining ability for yield and protein quality among modified endosperm opaque 2 tropical maize inbreds. Crop Sci. 33:1229-1234.

Prasanna, B.M., Vasal, S.K., Kasahun. B., Singh, N.N. 2001. Quality protein maize. Curr. Sci. 81:1308-1319.

Ram, L. 2014. Improvement of non QPM lines through introgression of QPM genes. PhD Thesis, BHU. Varanasi, India.

Ram, L., Singh, R., Singh, S.K. 2015. Study of combining ability using QPM donors as testers for yield and its component traits in maize (Zea mays L.). Sabrao J. Breeding and Genetics. 47:99-112.

Ribaut, J.M., Hoisington, D.A. 1998. Marker assisted selection: new tools and strategies. Trends Plant Sci. 3:236-239.

Senior, M.L., Murphy, J.P., Goodman, M.M., Stuber, C.W. 1998. Utility of SSRs for determining genetic similarities and relationships in maize using an agarose gel system. Crop Sci. 38:1088-1098. 
Singh, R., Srivastava, R.P. 2015. New quantitative trait loci (QTLs) for turcicum leaf blight in maize. J. of Biotech. Crop Sci. 5:35-43.

Sofi, P.A., Wani, S.A., Rather, A.G., Wani, S.H. 2009. Quality protein maize (QPM): genetic manipulation for the nutritional fortification of maize. J. Plant Breed. Crop Sci. 1:244-253.

Tanksley, S.D. 1993. Mapping polygenes. Annu. Rev. Genet. 27:205-233.

Vasal, S.K. 2001. High quality protein corn. In: Hallauer, A.R. (ed.), Specialty Corns. Second Edition. CRC Press. Boca Raton, FL, USA. pp. 85-129.

Villegas, E., Mertz, T.E. 1975. Simple chemical and biological methods used at Purdue University to evaluate cereals for protein quality. St. Bull 70:17-21.

Villegas, E., Ortega, E., Bauer, R. 1984. Chemical methods used at CIMMYT for determining protein quality in corn. CIMMYT. Mexico.

Visscher, P.M., Haley, C.S., Thompson, R. 1996. Marker assisted introgression in backcross breeding programs. Genetics 144:1923-1932.

Young, N.D., Tanksley, S.D. 1989. RFLP analysis of the size of chromosomal segments retained around "Tm-2 locus" of tomato during backcross breeding. Theor. Appl. Genet. 77:353-359. 